\title{
Solar radiation inside greenhouses covered with semitransparent photovoltaic film: first experimental results
}

\author{
Alvaro Marucci, ${ }^{1}$ Adolfo Gusman, ${ }^{2}$ Barbara Pagniello, ${ }^{1}$ Andrea Cappuccini ${ }^{1}$ \\ ${ }^{1}$ Department of Agriculture, Forests, Nature and Energy (D.A.F.N.E.); University of Tuscia, \\ Viterbo, Italy; ${ }^{2}$ External collaborator
}

\begin{abstract}
The southern Italian regions are characterized by climatic conditions with high values of solar radiation and air temperature. This has allowed the spread of protected structures both as a defense against critical winter conditions both for growing off-season. The major energy source for these greenhouses is given by solar energy and artificial energy is used rarely. So the problem in the use of greenhouses in these areas, if anything, is opposite to that of the northern areas. In these places you must try to mitigate often the solar radiation inside the greenhouses with suitable measures or abandon for a few months the cultivation inside these structures. The solar radiation intercepted by passive means can be used for other purposes through the uptake and transformation by the photovoltaic panels whose use however is problematic due to complete opacity of the cells. New photosensitive materials partially transparent to solar radiation onto flexible media, allow to glimpse the possibility of using them to greenhouses cover, getting the dual effect of partially screen the greenhouse and use the surplus to generate electricity. The research was carried out to evaluate the possibility of using a flexible photovoltaic film realized by the University of Rome Tor Vergata (research group of ECOFLECS project coordinated by prof. Andrea Reale) for covering greenhouses. Two greenhouses in small scale were built: one covered with photovoltaic film and one covered with EVA film for test. In both greenhouses during the first research period it was grown a variety of dwarf tomato.

The research was carried out comparing the solar radiation that enters into greenhouse in the summer (August 2012) and in winter conditions (December 2012) in both greenhouses.

The result show that the average ratio between the daily global solar radiation under the photovoltaic film and outside radiation is about
\end{abstract}

Correspondence: Alvaro Marucci, DAFNE, Department of Agriculture, Forests, Nature and Energy, University of Tuscia, 01100 Viterbo - Italy. Tel. +39.0761.357365 - Fax: +39.0761. 357453

E-mail: marucci@unitus.it

Key words: Mediterranean greenhouse, photovoltaic film, solar energy

Acknowledgements: The work was carried out in the research project "ECOFLECS" - leader: Aero Sekur SpA.

(C) Copyright A. Maruccil et al., 2013

Licensee PAGEPress, Italy

Journal of Agricultural Engineering 2013; XLIV(s2):e49

doi:10.4081/jae.2013.s2.e49

This article is distributed under the terms of the Creative Commons Attribution Noncommercial License (by-nc 3.0) which permits any noncommercial use, distribution, and reproduction in any medium, provided the original author(s) and source are credited.
$37 \%$, while between the radiation under EVA film and outside radiation is equal to approximately $63 \%$.

These result allow us to assert that during the hot season the use of photovoltaic film might be useful to mitigate the excesses of solar radiation into the greenhouse. During the cold season the use of this film not allows to achieve the minimum indoor climate conditions for the cultivation, however, it is possible to think to remove it in the periods of low solar radiation because it is a very flexible film.

\section{Introduction}

The Italian agricultural landscape is often characterized by the presence of greenhouses for horticulture that ensure the continuity of production during all year independently of seasonal climate change. These structures, using the greenhouse effect produced by solar radiation that passes through the transparent surfaces, allow to reach and maintain the values of the different climate parameters, such as the indoor air temperature and relative humidity to suitable levels for the needs of plants.

The greenhouses are widespread in central and northern Europe, where it is difficult to cultivate horticultural crop in the field for long periods of the year due to the unfavorable climate. In the southern Europe, however, they are mainly used for the cultivation of vegetables and flowers out of season. In these "Mediterranean greenhouses", the main supply of energy for creating the microclimatic conditions is given by solar energy and the artificial energy only in the short cold periods (mostly at night). The agronomic research, the last building technology of greenhouses and the choice of transparent cover materials are today increasingly oriented to reduce the use of artificial energy to contain the cost of production and the environmental impact (Vox et al., 2010; Marucci et al., 2011a; Campiglia et al., 2007).

These greenhouses are especially prevalent in the central and southern Italy and in all countries bordering the Mediterranean such as Spain, Greece, Israel, etc. In these locations the intensity of solar radiation reaching the Earth's surface during some periods of the year is often excessive in relation to the needs and it causes the raising of the indoor air temperature to levels that are not tolerated by crops and by workers. Not long ago, during the summer months, the productive activity in greenhouses was suspended or if the cost of roofing materials was low, the transparent covering was removed transforming the protected crop in an open field cultivation. This practice has been recently resumed using the open roof greenhouse that completely cancels the greenhouse effect during periods of intense solar radiation. As an alternative to these solutions, we can use shade cloth that is placed on the greenhouse roof, cooling systems or, more simply, we can increase the natural ventilation through large openings or use mechanical ventilation. These solutions involve a significant increase in the costs of construction and operation.

Therefore, the main problem in these geographical areas is to try to 
reduce the solar radiation into the greenhouse during summer months. Passive systems, such as the shade cloth or painting the cover (no longer in use), are able to reject only a portion of solar radiation through a significant reduction of the optical transmittance of the covering. This reduction can also reach very high values (greater than $80 \%$ ) but it depends by the needs of the plants that require well identified quantitative and qualitative levels of light for their biological activity (Hurd, 1983; Kittas and Bailie, 1998 ; Kittas et al., 1999).

The solar radiation rejected by passive means of protection (shade cloth and nets, etc..) could be more conveniently used for other purposes with appropriate means of uptake and transformation. Among these are of particular interest the photovoltaic panels that turn the solar energy into electrical energy.

The complete opacity of the material used for the cells (silicon), however, hinders the use of photovoltaic on greenhouses because the cells can be not crossed, at least in part, by solar radiation. The research of other materials to the photovoltaic energy production in substitution of silicon (Hua et al., 2009; Shin et al., 2010) that are partly transparent to solar radiation and the possibility of using flexible substrates for cells, give us a hope to apply such materials on greenhouse covering. The effect of the application of such materials is to reduce the radiation inside the greenhouse during periods of excess and use the surplus to produce electricity (Marucci et al., 2012; Marucci et al., 2013a).

A recent study on the applicability of photovoltaic systems on the Mediterranean greenhouses showed that the crop planning allows us to make better use of solar energy (Marucci et al., 2013b; Marucci et al., 2011b; Rouphael et al., 2010). For example, the tomato cultivation from October to April as well as having some energy surplus in the clear days of growing period, gives the full availability of solar energy in the summer months when the crop in the greenhouse is suspended.

At the University of Tuscia there is an ongoing research to evaluate the possible use of semi-transparent photovoltaic film as a greenhouse covering material. The work shows the results obtained by this research.

\section{Materials and methods}

The research was carried out on a recent model of organic photovoltaic film developed by the University of Rome Tor Vergata.

This film was made by inserting semitransparent photovoltaic modules between two layers of poly-vinyl-butyral. Spectrophotometric laboratory analysis has showed that the photovoltaic film has a transmittance of $48 \%$ and $69 \%$ respectively in the field of visible and near infrared radiation (Figure 1) (Marucci et al., 2013a).

The refractive index of this material was calculated to determine the solar radiation reflected by a transparent surface, using the following equation:

$$
\tau=\frac{4 n_{1} n_{2}}{\left(n_{1}+n_{2}\right)^{2}}
$$

where $\tau t$ is the transmittance, $n_{1}$ is the refractive index of air and $n_{2}$ is the refractive index of the film. The values of this index were 4.341326 and 4.206651 respectively between $380 \mathrm{~nm}$ and $760 \mathrm{~nm}$ (visible) and $380 \mathrm{~nm} 1100 \mathrm{~nm}$ (visible and near infrared).

This photovoltaic film was used for covering the roof of a model of greenhouse specifically developed. A second model was covered with Eva film (Figures 2,3 and 4).

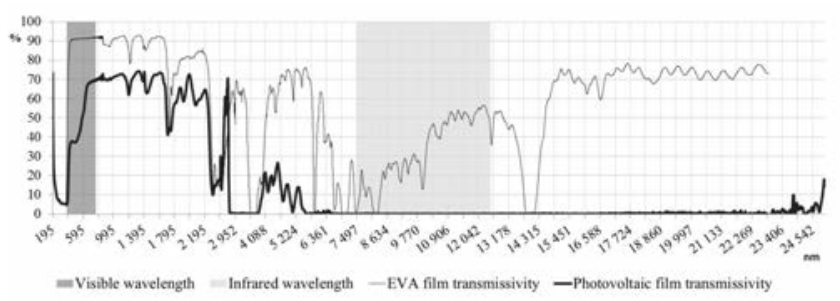

Figure 1. Transmissivity of photovoltaic and EVA films to solar radiation.

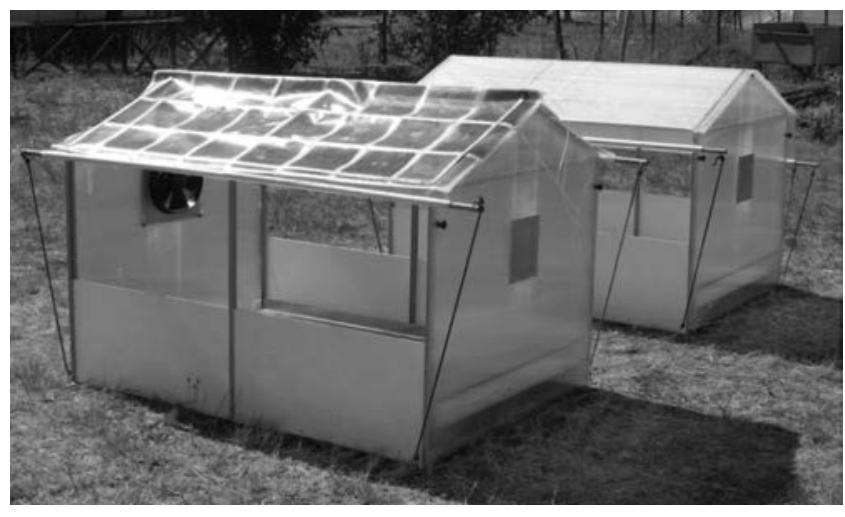

Figure 2. The two models covered with photovoltaic and EVA films.

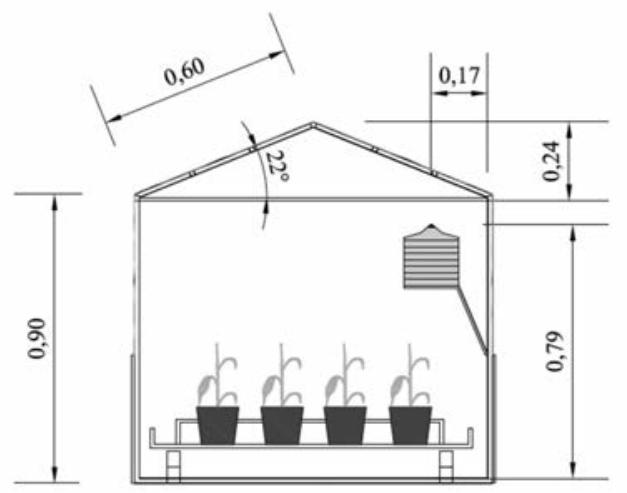

Figure 3. Section of the experimental model.

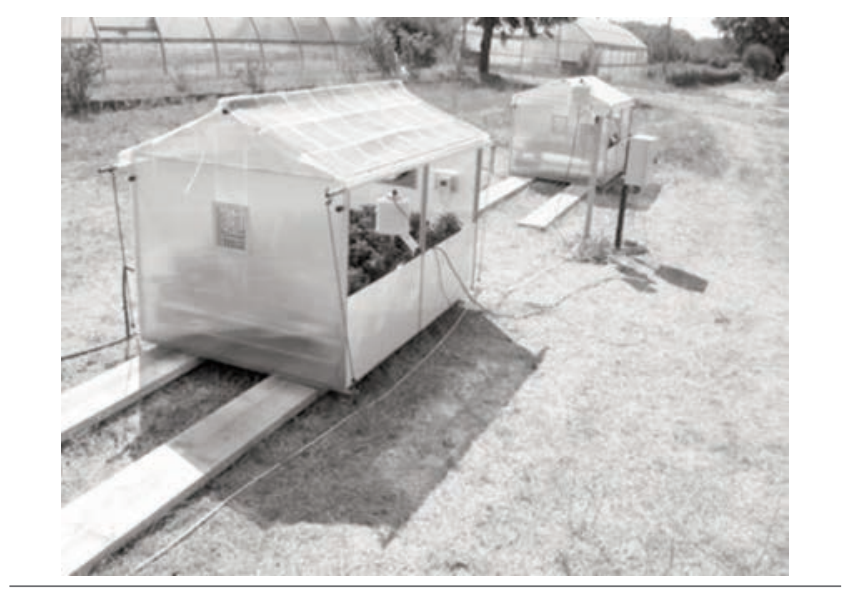

Figure 4. Models during the test. 
In particular each model has, in plan, a length of $1.60 \mathrm{~m}$, a width of $1.13 \mathrm{~m}$, a height to the eaves of $0.90 \mathrm{~m}$ and to the ridge of $1.14 \mathrm{~m}$. The roof pitch angle is $22^{\circ}$.

This angle value was chosen to make most similar models to fullscale greenhouses although it is known that an angle between $33^{\circ}$ and $40^{\circ}$ it seems, at latitude of Italy, more convenient to pick up the greatest amount of solar energy by south oriented surfaces. These last values of the roof pitch for a greenhouse do not allow to capture the greatest amount of solar energy (Candura and Gusman, 1977) and create different problems in form and static structure.

The two transversal walls of each model were coated with a four layers polycarbonate sheet. In one a fan of $1000 \mathrm{~m}^{3} \mathrm{~h}^{-1}$ was installed while in the other an aluminum manually adjustable shutter. The longitudinal walls were closed with opaque panels to a height of $0.40 \mathrm{~m}$ while the remaining $0.50 \mathrm{~m}$ were closed with an EVA film of $0.18 \mathrm{~mm}$ completely rolled up to the eaves. This closure has been used since the end of September while in the months of August and September has been kept rolled to promote a more effective ventilation.

Sensors to measure temperature, relative humidity of the air and solar radiation were installed, in each model, and precisely:

- $\mathrm{N}^{\circ} 1$ Thermo-hygrometer CS215 with weather shelter

- $\mathrm{N}^{\circ} 1$ Pyranometer CS300

The same instruments were installed in the greenhouse models and outside.

The data collected from these sensors were gathered into a CR1000 Datalogger with 16 channels and 8 IO ports. On a solid memory the instantaneous values of minimum, maximum and mean of temperature and air humidity, at 15-minute intervals, were recorded. Regarding the measurement of radiation, always with the same scan time, the instantaneous value in $\mathrm{kWm}^{-2}$ and the cumulative value in $\mathrm{MJm}^{-2}$ were recorded.

\section{Identification of clear days}

In order to evaluate the possibility of adopting the photovoltaic film for covering greenhouses, have been taken into account the solar radiation data on clear days of August and December. In the place where the greenhouses have been installed these months are usually characterized by extreme weather conditions.

For identifying the clear days, the values of the solar radiation measured by the outside radiometer with those obtained by the calculation with the mathematical model proposed by Hottel (Duffie et al., 1991) were compared. The model uses the extraterrestrial solar radiation, the Julian day, the zenith angle of the sun and the transmittance of the atmosphere:

$\begin{array}{ll}\mathrm{Rg}=\text { global radiation at ground }=\mathrm{Rb}+\mathrm{Rd} & {\left[\mathrm{Wm}^{-2}\right]} \\ \mathrm{Rb}=\text { direct radiation at ground }=\mathrm{Re}_{\mathrm{b}} \operatorname{cosq}_{\mathrm{z}} & {\left[\mathrm{Wm}^{-2}\right]} \\ \mathrm{Rd}=\text { diffuse radiation at ground }=\mathrm{Re}_{{ }_{\mathrm{d}} \cos \mathrm{q}_{\mathrm{z}}} & {\left[\mathrm{Wm}^{-2}\right]}\end{array}$

where:

$\mathrm{Re}=$ outer radiation $=1367\left(1+0.033 \cos \left(360 / 365^{*} \mathrm{n}\right)\right)\left[\mathrm{Wm}^{-2}\right]$

$\mathrm{n}=$ Julian day

$\tau_{b}=$ transmissivity of the atmosphere to the direct radiation $=$

$\mathrm{A}_{\mathrm{o}}+\mathrm{A}_{1} \times \mathrm{e}^{\frac{-K}{\cos \theta_{2}}}$

$\tau_{\mathrm{d}}=$ transmissivity of the atmosphere to the diffuse radiation $=0.271-$

$0.294 \tau_{\mathrm{b}}$

$$
\begin{aligned}
& A_{0}=\left[0.4237-0.00821(6-\mathrm{A})^{2}\right][1+0.03 \sin (\pi((91+\mathrm{n}) / 182))] \\
& A_{1}=\left[0.5055-0.00595(6.5-\mathrm{A})^{2}\right][1+1.01 \sin (\pi((91+\mathrm{n}) / 182))] \\
& K=\left[0.27110 .01858(2.5-\mathrm{A})^{2}\right][1.01-0.01 \sin (\pi((91+\mathrm{n}) / 182))]
\end{aligned}
$$

$\mathrm{A}=$ altitude $[\mathrm{km}]$

$\cos \theta_{z}=\sin \phi \sin \delta+\cos \varphi \cos \delta \cos \omega$

$\phi=$ local latitude;

$\delta=$ Inclination of the sun

$\omega=$ hour angle.

Twelve clear days in August and twelve clear days in December have been identified (Figure 5, 6 and 7).

\section{Calculation of the solar radiation in the greenhouse models}

For each of these clear days was quantified global solar radiation (direct and diffuse) recorded inside the two prototypes and outside of them. Comparing these values, it was possible to calculate the global average transmittance of the two types of coverage.

For each clear day and for each transparent surface, the solar radiation inside of the prototypes has been evaluated by a mathematical model that uses the data of theoretical and measured solar radiation outside the prototypes, the values of the transmittance of the materials and the calculated refractive indices. In this model the reflection phe-

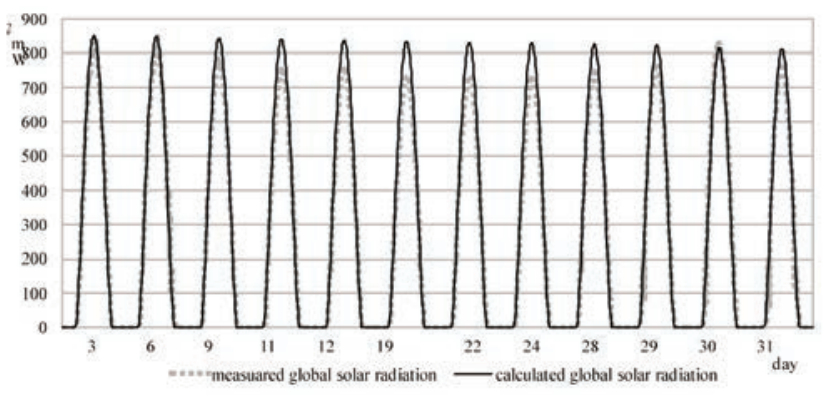

Figure 5. Global solar radiation measured and calculated in August.

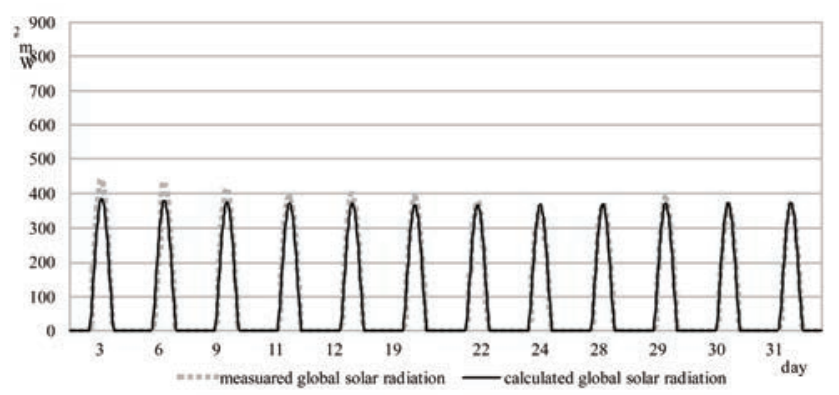

Figure 6. Global solar radiation measured and calculated in December. 
nomenon that has been considered, essentially depends on the refractive index and the angle of incidence of the solar rays that is particularly important for the material of the photovoltaic film.

Daily values of global solar radiation that passes through the individual transparent surfaces were calculated on the level of the radiometers located in each model. This evaluation was made using the solar radiation values calculated by Hottel equation and those recorded by the outside radiometer.

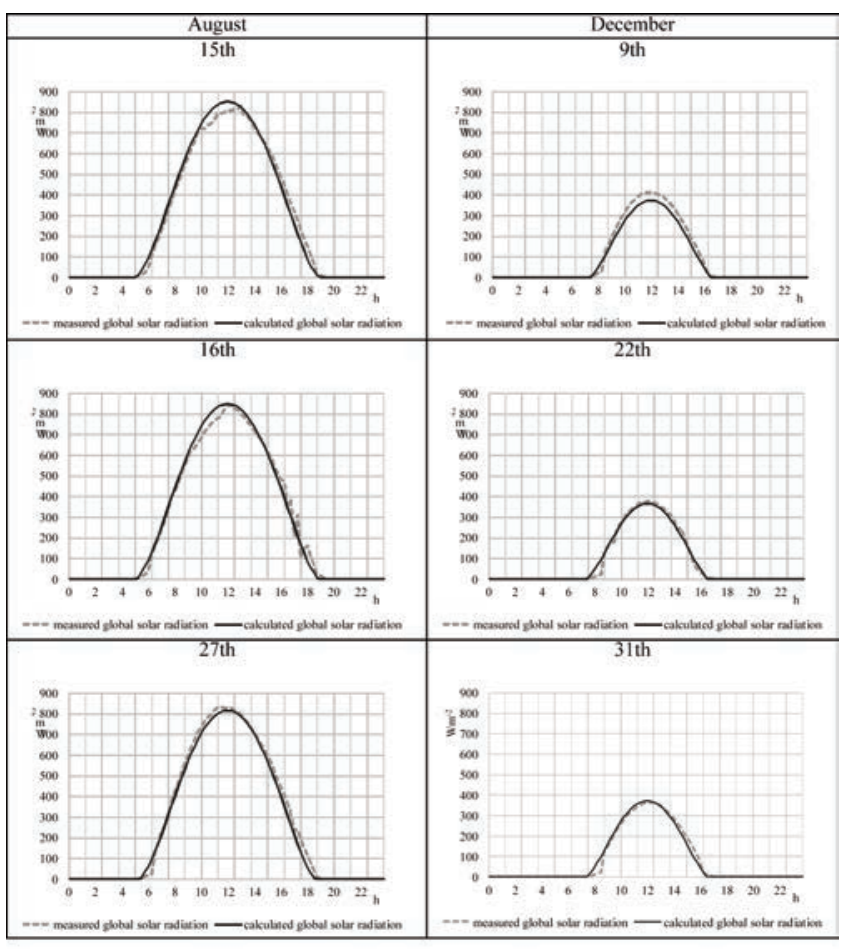

Figure 7. Global solar radiation measured and calculated in some representative days.

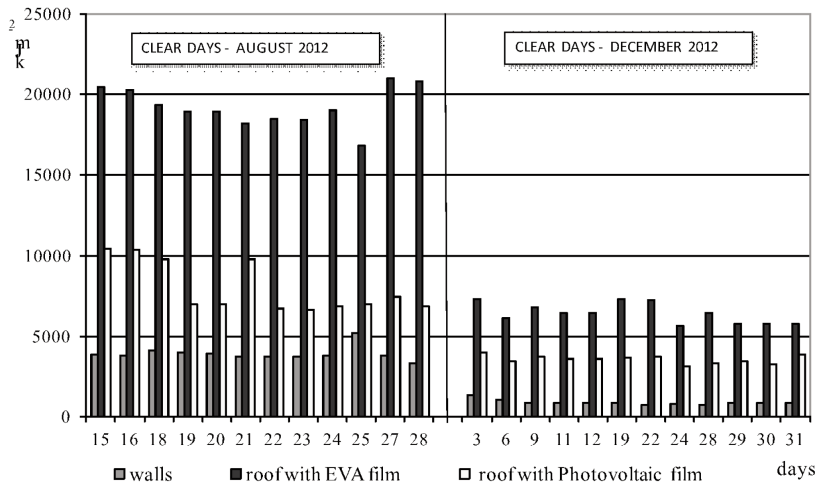

Figure 8. Comparison of solar radiation measured for transparent walls and roof.

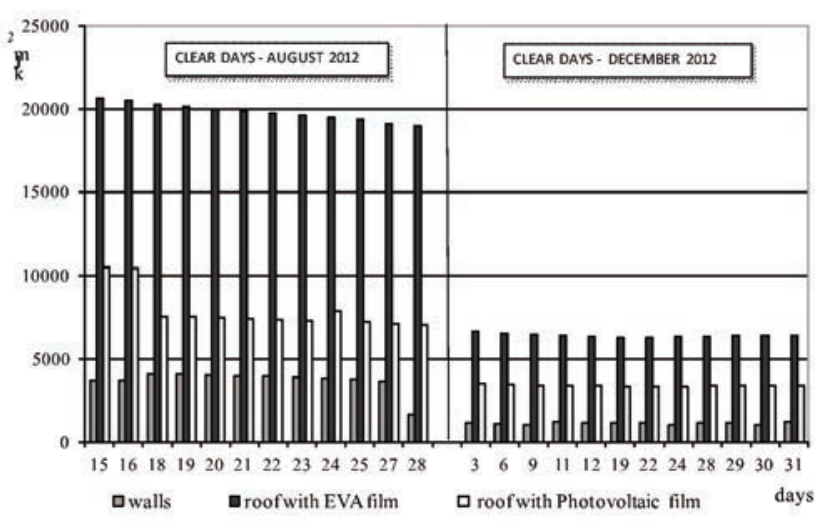

Figure 9. Comparison of solar radiation calculated for transparent walls and roof.

Table 1. measured and calculated global solar radiation.

\begin{tabular}{|c|c|c|c|c|c|}
\hline Clear days & $\begin{array}{c}\text { August } 2012 \\
\text { Measured global } \\
\text { solar radiation } \\
{\left[\mathrm{kJm}^{-2}\right]}\end{array}$ & $\begin{array}{c}\text { Calculated global } \\
\text { solar radiation } \\
{\left[\mathrm{kJm}^{-2}\right]}\end{array}$ & $\begin{array}{l}\text { Clear days } \\
\text { solar radiation }\end{array}$ & $\begin{array}{c}\text { December } 2012 \\
\text { Measured global } \\
\text { solar radiation } \\
{\left[\mathrm{kJm}^{-2}\right]}\end{array}$ & $\begin{array}{c}\text { Calculated global } \\
\text { solar radiation } \\
{\left[\mathrm{kJm}^{-2}\right]}\end{array}$ \\
\hline 15 & 24110 & 24402 & 3 & 8729 & 7869 \\
\hline 16 & 23644 & 24261 & 6 & 7647 & 6872 \\
\hline 18 & 22434 & 23972 & 9 & 8198 & 7335 \\
\hline 19 & 21919 & 23825 & 11 & 7864 & 7064 \\
\hline 20 & 21647 & 23678 & 12 & 7861 & 7085 \\
\hline 21 & 21055 & 23529 & 19 & 7492 & 6759 \\
\hline 22 & 21018 & 23377 & 22 & 7086 & 6431 \\
\hline 23 & 21198 & 23224 & 24 & 6890 & 6222 \\
\hline 24 & 21818 & 23068 & 28 & 7313 & 6568 \\
\hline 25 & 20138 & 22909 & 29 & 7568 & 6804 \\
\hline 27 & 22663 & 22749 & 30 & 7100 & 6381 \\
\hline 28 & 21128 & 24402 & 31 & 7184 & 6461 \\
\hline
\end{tabular}


Table 2. Measured global radiation inside and outside of models and transmittance of EVA and photovoltaic films.

\begin{tabular}{|c|c|c|c|c|c|}
\hline Clear days & $\begin{array}{l}\text { Global solar } \\
\text { radiation } \\
{\left[\mathrm{kJm}^{-2}\right]}\end{array}$ & $\begin{array}{c}\text { Radiation in Greenhouse } \\
\text { with photovoltaic film } \\
{\left[\mathrm{kJm}^{-2}\right]}\end{array}$ & $\begin{array}{c}\text { August } 2012 \\
\text { Radiation in Greenhouse } \\
\text { with EVA film } \\
{\left[\mathrm{kJm}^{-2}\right]}\end{array}$ & $\begin{array}{c}\text { Mean global transmittance } \\
\text { of photovoltaic film } \\
{[\%]}\end{array}$ & $\begin{array}{c}\text { Mean global } \\
\text { transmittance of EVA film } \\
{[\%]}\end{array}$ \\
\hline 15 & 23892 & 9920 & 15638 & 42 & 65 \\
\hline 16 & 23153 & 9085 & 14667 & 39 & 63 \\
\hline 18 & 22441 & 8899 & 14388 & 40 & 64 \\
\hline 19 & 21938 & 8711 & 13878 & 40 & 63 \\
\hline 20 & 21673 & 8702 & 13566 & 40 & 63 \\
\hline 21 & 20993 & 8431 & 13059 & 40 & 62 \\
\hline 22 & 21003 & 8467 & 13004 & 40 & 62 \\
\hline 23 & 21187 & 8359 & 12891 & 39 & 61 \\
\hline 24 & 21875 & 8239 & 12764 & 38 & 58 \\
\hline 25 & 19327 & 7268 & 10964 & 38 & 57 \\
\hline 27 & 22561 & 8098 & 13111 & 36 & 58 \\
\hline 28 & 21086 & 7712 & 12776 & 37 & 61 \\
\hline Mean & 21761 & 8491 & 13392 & 39 & 61 \\
\hline
\end{tabular}

\section{Results}

The analysis of the global radiation measured outside (Table 1) shows that in the clear days of August, the mean global radiation outside is about $21897 \mathrm{kJm}^{-2}$ while in the clear days of December, this value drops to about $7577 \mathrm{kJm}^{-2}$.

Comparing the measured values to those calculated using the model proposed by Hottel, it appears that there is an overestimation of the mean global radiation about 7.8\% in days of August, while in December there is an underestimation of around 9.9\%. These differences, in our opinion, are essentially due to the haze in August caused by air humidity. In winter, however, the clear days almost always coincide with the days when the wind blows from the northern quadrant and removes the haze. For these reasons, we have decided that it was possible to use the calculated values of solar radiation to evaluate the solar energy inside the greenhouse models.

Table 2 shows that in the clear days of August into greenhouse covered with photovoltaic film, the radiation is $37 \%$ less than the radiation recorded in the greenhouse covered with the EVA film. This difference increases to $45 \%$ in December.

In absolute terms, the maximum daily global radiation measured in August into the greenhouse covered with photovoltaic film was 9920 $\mathrm{kJm}^{-2}$ against $15638 \mathrm{kJm}^{-2}$ into the greenhouse covered with EVA film. During the month of December, these values decrease respectively to $2926 \mathrm{kJm}^{-2}$ and $5319 \mathrm{kJm}^{-2}$.

Considering that in the experimental area the clear days were about $30 \%$ of the days of the month, it is to be inferred that this type of the greenhouse would be unusable especially for most of the month of December. During this month, the average daily radiation in the greenhouse covered with photovoltaic film amounted to $2077 \mathrm{kJm}^{-2}$ against $3648 \mathrm{kJm}^{-2}$ measured in the greenhouse covered with EVA film.

These results are an obvious consequence of the lower transmittance of the photovoltaic film $-38 \%$ than EVA film) that, if during August this characteristic can mitigate the excesses of radiation, during December doesn't allows to achieve a functional use of greenhouse without artificial energy subsidies (heating and lighting).

Another test was performed using mathematical models for determining the single rates of solar energy that penetrated into the green-

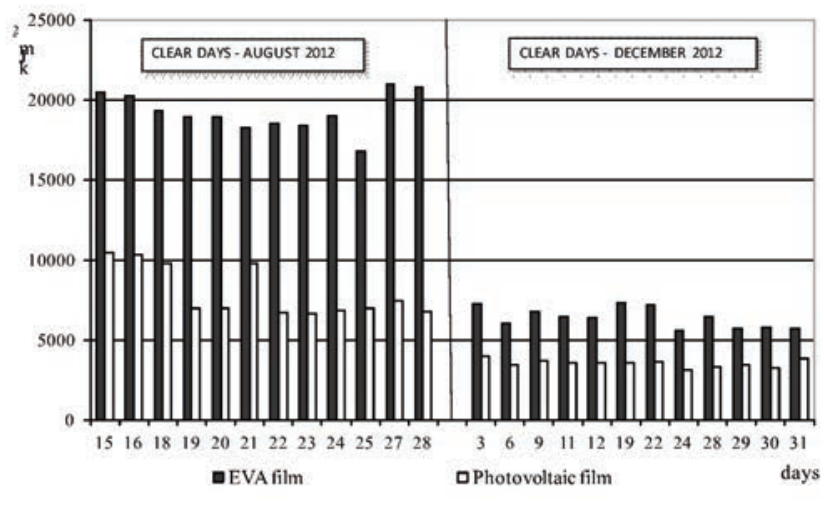

Figure 10. Comparison of the measured solar radiation transmitted by EVA and Photovoltaic films.

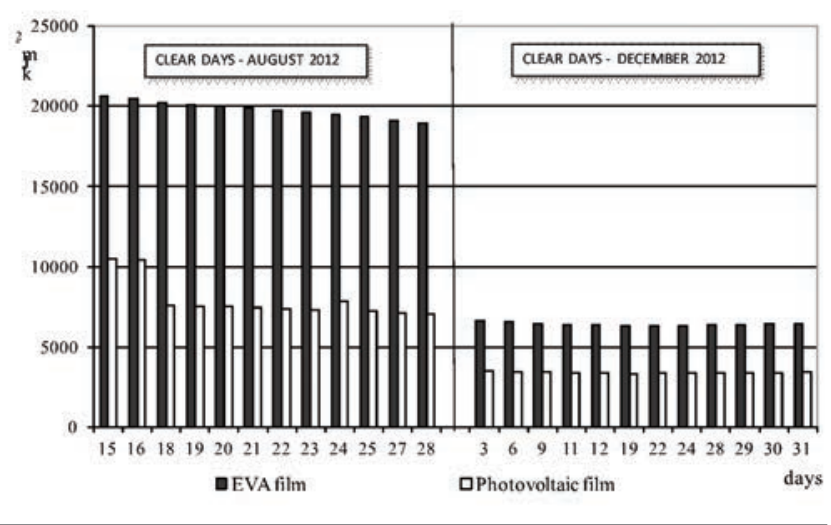

Figure 11. Comparison of the calculated solar radiation transmitted by EVA and Photovoltaic films. 
house models through the transparent surfaces using both the solar radiation calculated values and those measured with the radiometer placed outside. The results of this analysis are shown inFigures 8, 9, 10 and 11.

The comparison between the global solar energy into greenhouse model and the energy that passes through the roof reveals that through this surface penetrates inside the $85 \%$ of energy in the case of EVA film and the $73 \%$ in the case of photovoltaic film.

It should be remembered, moreover, that the incidence of the transparent surface of the vertical walls on the roof surface of the models used is greater than that which occurs generally in the greenhouses in real scale. We tried to reduce this difference by making opaque the lower parts of these structures.

These results confirm that in a greenhouse the greater contribution of solar energy occurs through the roof and considering that the effect of transversal and longitudinal walls is greater when the greenhouse is covered with photovoltaic film, it is advisable to use highest greenhouses with large transparent longitudinal and transversal walls to try to improve the level of inside radiation.

Analyzing the figures 10 and 11 we clearly see the marked difference between the solar energy that pass through the roof in EVA film and the one in photovoltaic film. This difference is about 70\% in August and $50 \%$ in December and this is due to the effect of the reflection of sunlight on the covering. In winter, because of the lower altitude of the sun on the horizon, the rays of the sun hit in oblique the covering increasing its reflectivity.

\section{Conclusions}

The experimental results and those obtained by comparison with the mathematical models used allow us to make some final considerations.

The photovoltaic film would be useful in the summer to mitigate the excesses of solar radiation that occur especially in central and southern areas of Italy. In these areas, in fact, during the summer season the cultivations inside greenhouses are always difficult and often these structures are left unused if there are not efficient cooling systems. Also, the reduction of brightness into the greenhouse, due to low transmissivity of photovoltaic film, can be considered as a positive element for the species that do not tolerate high light levels.

The biggest problems you have, of course, during the winter season when in greenhouses covered with traditional plastic films occurring micro indoor climate conditions were not always favorable for culture due to a not sufficient greenhouse effect. If you reduce the contribution of solar energy with a less transparent coverage as the photovoltaic film, it is difficult to think about the use of this material for covering greenhouse. The values measured inside the photovoltaic greenhouse, in our opinion, are quite low to ensure an adequate greenhouse effect also for cultivation of plants which are thermally less demanding. You might think about removing the photovoltaic film during wintertime (e.g. rolling up the film) and as soon as the solar radiation exceeds certain levels, this covering could be extended to capture solar energy and reduce internal levels of energy.

The difficulties in applying similar solutions are technical and economical. A cost benefit analysis only, which involves the entire greenhouse system can give a more certain answer to the possibility of produce photovoltaic energy using these systems.

\section{References}

Campiglia E., Colla G., Mancinelli R., Rouphael Y., and Marucci A. 2007. Energy balance of intensive vegetable cropping systems in central Italy. Acta Horticulturae, vol. 747, 185-191.

Candura A., Gusman A. 1977. Studio per una migliore utilizzazione dell'energia solare nelle serre in vetro. Colture protette, no. 10, 2340.

Duffie J. A. and Beckman W. A. 1991. Solar Engineering of Thermal Processes. John Wiley \& Sons, New York, NY, USA.

Hailin Hua, Sheng-ChinKung, Li-MeiYang, Nicho, M.E., M.Penner, R. 2009. Photovoltaic devices based on electrochemical-chemical deposited CdS and poly3-octylthiophene thin films Solar EnergyMaterials \& Solar Cells, 93, 51-54.

Hurd, R.G. 1983. Energy saving techniques in greenhouses and their effects on the tomato crops, Scientia Horticulturae, 33, 94-101.

Kittas C. and Bailie A. 1998. Determination of the spectral properties of several greenhouse cover materials and evaluation of specific parameters related to plant response. Journal of Agricultural Engineering Research, vol. 71, no. 2, 193-202.

Kittas C., Baille A., and Giaglaras P. 1999. Influence of covering material and shading on the spectral distribution of light in greenhouses. Journal of Agricultural Engineering Research, vol. 73, no. 4, 341-351.

Marucci A., Campiglia E., Colla G., and Pagniello B. 2011a. Environmental impact of fertilization and pesticide application in vegetable cropping systems under greenhouse and open field conditions. Journal of Food, Agriculture and Environment, vol. 9, no. 3$4,840-846$.

Marucci A. and Pagniello B. 2011b. Simulation of the growth and the production of the tomato in typical greenhouses of the Mediterranean environment," Journal of Food, Agriculture and Environment, vol. 9, no. 3-4, 407-411.

Marucci A., Monarca D., Cecchini M., Colantoni A., Manzo A., Cappuccini A. 2012. The semitransparent photovoltaic films for Mediterranean greenhouse: A new sustainable technology. Mathematical Problems in Engineering, vol. 2012, Article ID 451934, 14 pages.

Marucci A., Monarca D., M. Cecchini, M., Colantoni, A., Allegrini E., and Cappuccini A., 2013a. Use of Semi-transparent Photovoltaic Films as Shadowing Systems in Mediterranean Greenhouses. ICCSA 2013, Part II, LNCS 7972, 231-241.

Marucci A., Gusman A., Pagniello B., Cappuccini A., 2013b. Limits and prospects of photovoltaic covers in mediterranean greenhouse. Journal of Agricultural Engineering, vol. 44, no. 1, 1-8.

Rouphael Y., Cardarelli M. T., Ajouz N., Marucci A., and Colla G. 2010. Estimation of eggplant leaf number using thermal time model. Journal of Food, Agriculture and Environment, vol. 8, no. 2, 847850.

Shin G.H., Allen C.G., Potter B.G. Jr. 2010. RF-sputtered Ge-IT0 nanocomposite thin films for photovoltaic applications. Solar EnergyMaterials \& Solar Cells, vol. 94, 797-802.

Vox G., Teitel M., Pardossi A., Minuto A., Tinivella F., Schettini E. 2010. Chapter 1: Sustainable Greenhouse Systems in "Sustainable Agriculture: Technology, Planning and Management", Augusto Salazar e Ismael Rios Editors, Nova Science Publishers, Inc. NY USA, ISBN: 978-1-60876-269-9: 1-79. 